\title{
Metals impact into the Paranaguá Estuarine Complex (Brazil) during the exceptional flood of 2011
}

\author{
Marilia Lopes da Rocha1,2,3*, Fabian Sa ${ }^{4}$, Monica Soares Campos ${ }^{5}$, Marco Tadeu Grassi ${ }^{6}$, Tatiane \\ Combi $^{1,3}$, Eunice da Costa Machado ${ }^{7}$ \\ ${ }^{1}$ Centro de Estudos do Mar, Universidade Federal do Paraná - UFPR \\ (Av. Beira Mar s/n, 83255-000, Pontal do Paraná - PR, Brasil) \\ ${ }^{2}$ Departamento de Química-Física, Facultad de Ciencias del Mar y Ambientales, Universidad de Cádiz, UNESCO/UNITWIN WiCoP, \\ Campus de Excelencia International del Mar (CEIMAR) \\ (Polígono Río San Pedro s/n, Puerto Real 11510, Cádiz, Spain) \\ ${ }^{3}$ Centro Interdipartimentale di Ricerca per le Scienze Ambientali (C.I.R.S.A.), University of Bologna \\ (Campus di Ravenna, 48123 Ravenna, Italy) \\ ${ }^{4}$ Departamento de Oceanografia - DOC, Base Oceanográfica, Universidade Federal do Espírito Santo, UFES \\ (Rodovia ES-010, s/n, Bairro Coqueiral 29199-010, Aracruz, ES, Brasil) \\ ${ }^{5}$ Fundacentro - Fundação Jorge Duprat Figueiredo de Segurança e Medicina do Trabalho \\ (Rua Capote Valente, 710, Jardim Paulista 05409-002, São Paulo - SP, Brasil) \\ ${ }^{6}$ Departamento de Química - Universidade Federal do Paraná \\ (81531-980 Curitiba - Paraná, Brasil) \\ ${ }^{7}$ Universidade do Rio Grande - FURG, Instituto de Oceanografia - Lab. de Hidroquímica,Campus Carreiros \\ (Av. Itália, km 8, s/n 96203-900 - Rio Grande - RS, Brasil) \\ *Corresponding author: marilia.lopes@alum.uca.es
}

\section{Abstract}

Particulate and dissolved metal concentrations were determined after the largest flood in the last 30 years on the east-west axis of the Paranaguá Estuarine Complex (PEC) and compared to the those of the dry period at two stations. Results confirmed that the flood greatly affected riverine outflows and the behavior of metals in the PEC. In particular, a sharp decrease in salinity was followed by extremely high SPM concentrations leading to a decrease in DO concentrations at both stations. For the dissolved phase, ANOSIM analysis showed a significant dissimilarity at each station between the sampled periods, whereas for the particulate phase this dissimilarity was found only for the samplings taken at the Antonina Station. KD values suggested dissolved $\mathrm{Cu}$ behavior was related to the presence of organic complexes and dissolved Mn had sediment resuspension of redox sediments and or/pore water injection as sources. Metal concentrations were lower than in polluted estuaries, though high enrichment factors found after the flood pointed to the influence of anthropogenic sources. In conclusion, the flood's influence was more evident at the Antonina Station, due to its location in the upper estuary, whereas in Paranaguá a high SPM content with low metal concentration was found, following the common pattern generally found in other marine systems subject to heavy rainfall events.

Descriptors: Dissolved metals, Particulate metals, Flood event, partition coefficient.

Submitted on: 14/06/2016

Approved on: 11/10/2016

http://dx.doi.org/10.1590/S1679-87592017127706501

\section{RESUMo}

Com o objetivo de avaliar a influência do maior evento de enchente dos últimos 30 anos no Complexo Estuarino de Paranaguá (CEP), ocorrido em 2010, concentrações de metais na fase particulada e dissolvida foram medidas em duas estações amostrais, e comparadas ao período seco. Os resultados confirmaram a influência desse evento no aumento do fluxo dos rios e no comportamento dos metais no CEP. Uma acentuada diminuição na salinidade, concomitante ao aumento de material particulado em suspensão, gerou a diminuição das concentrações de oxigênio dissolvido nas duas estações amostradas. A análise de ANOSIM indicou ausência de similaridade entre ambas as estações e períodos amostrados, enquanto que para a fase particulada essa diferença foi evidente apenas para a estação de Antonina. Os valores do coeficiente de partição (KD) sugeriram um input de manganês dissolvido por meio de processos de oxi-redução. As concentrações de metais registradas foram menores do que as encontradas em estuários poluídos; no entanto, o aumento do Fator de Enriquecimento após o evento de inundação sugeriu a influência de fontes antrópicas. Como conclusão geral, a influência do evento de inundação foi mais evidente na estação de Antonina, principalmente devido a sua localização na parte superior do estuário, enquanto que em Paranaguá o aumento do SPM foi acompanhado de uma diminuição na concentração de metais, seguindo o comportamento de metais registrados em outros estuários após eventos de inundação.

Descritores: Metais na fase dissolvida, Metais no particulado, eventos de inundação, coeficiente de partição. 


\section{INTRODUCTION}

Water resources management is currently one of the most important issues of concern to the international community. There are increasing evidences that climate changes and human activities are affecting water resources negatively, e.g. increasing the frequency of floods; contaminating waterbodies; depleting water sources (MILLY et al., 2002). Anthropogenic disturbances and natural climate change can be understood by studying the relationship between water and sediment discharge, the transport of trace elements and other substances and the complex interactions of these processes in estuarine environments (ZHANG et al., 2002).

In March 2011, an extreme rainfall event caused severe flooding in the region of the Paranaguá Estuarine Complex (PEC), leading to landslides and partial destruction of urban areas, mainly around the city of Antonina. During these events of intense river flow, large volumes of water and large amounts of newly eroded material containing the mobilised contaminants retained in the soil were swept into the estuary (MASSON et al., 2006). Considering that metals are widely present in environmental compartments and enter the coastal ecosystems mainly through rivers and estuaries, understanding their behavior can be an important tool for environmental studies, especially regarding extreme events.

Estuarine systems are characterised by strong physicalchemical and hydrodynamic gradients, responsible for modifying the distribution of trace elements between the particulate and dissolved phases (LI et al., 1984). The geochemical processes that affect the partitioning of these elements are: flocculation and coagulation of colloidal material (BIATI; KARBASSI, 2012); adsorption and desorption at low salinities (ZWOLSMAN; VAN ECK,1999); mixing of suspended material from rivers and particles of marine origin (MARTINO et al., 2002); mobilisation of Fe and $\mathrm{Mn}$ in reduced sediments (MORRIS et al., 1982) and resuspension of sediments (TURNER, 1996).

Although most studies on the behavior of major and trace elements are focused on seasonal and spatial variation along the estuary (HATJE et al., 2003; BELTRAME et al., 2009), approaches using anchor (settled) (or anchored fixed) stations offer the opportunity to investigate the importance of estuarine mixing and temporal variation.

Despite the fact that the PEC is of considerable economic and ecological importance to Southern Brazil
(POSSATTO et al., 2015) and represents a key region for the environmental preservation and social/ economic development of the state of Paraná, the impact of metal concentrations in the water column of this system has not yet been assessed. Previous studies have focused on metal concentrations in sediments (SÁ et al., 2015; CHUOERI et al., 2009) and in catfish (ANGELLI et al., 2013).

Therefore, in view of ongoing climate change and rising temperature (SPALDING et al., 2014) leading to more frequent flooding, which may involve an increase in both erosion and fluvial discharge and consequently a potential enrichment of trace elements in the PEC, it was decided to investigate whether this pattern could be applied to the PEC by undertaking sampling after an extreme rainfall event and a dry period to assess the distribution of trace and major elements in the particulate and dissolved phase, to investigate the source of the metals and their behavior and mobility in this system under these two different weather conditions.

\section{MATERIAL AND METHODS}

\section{STUDY AREA}

The PEC can be divided into two main sections: (i) the western section, formed by Paranaguá and Antonina bays (E-W) and (ii) the northern section, consisting of the Pinheiros and Laranjeiras bays (N-S) (LANA et al., 2001). The present study was undertaken in the $\mathrm{E}-\mathrm{W}$ section (Figure 1). The depth in the E-W section ranges from 5.4 $\mathrm{m}$ to $33 \mathrm{~m}$, the main rivers being the Cachoeira and the Nhundiaquara which together contribute $82 \%$ of the total discharge of continental water into the estuarine system.

With a total area of $551.8 \mathrm{~km}^{2}$, the PEC $\left(25^{\circ} 30^{\prime} \mathrm{S}\right.$, $\left.48^{\circ} 25^{\prime} \mathrm{W}\right)$ is the third most important estuarine environment on the Brazilian coast (COMBI et al., 2013). The region is environmentally significant and contains a large fraction of the preserved Atlantic Forest of the Guaraqueçaba Environmental Protection Area (EPA) and Environmental Conservation Units (e.g. Mel Island State Park and Superagüi National Park).

The surrounding area has been subject to rapid, hazard human occupation and urban development (MARTINS et al., 2010), especially in the cities of Paranaguá and Antonina, which house $65 \%$ of the population of the coastal area of the Paraná state. The human activities of the region relate mainly to the grain-exporting port of Paranaguá, the largest for grain shipment in South America, and to that of Antonina which, despite its smaller capacity, contributes 


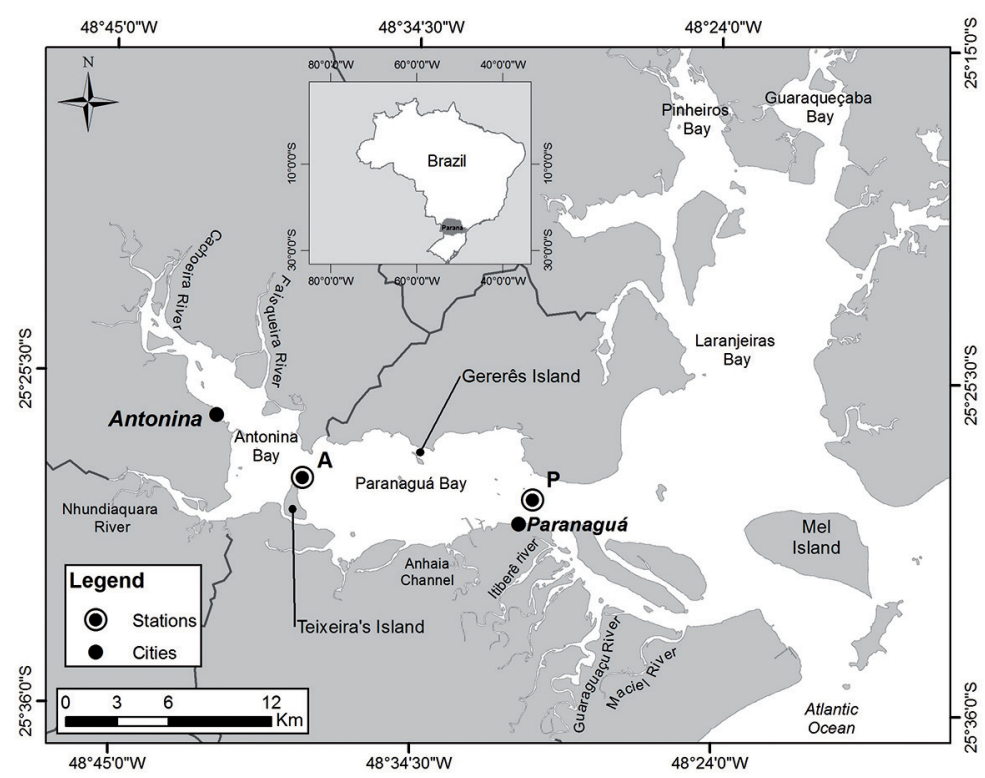

Figure 1. The Paranaguá Estuarine Complex (PEC) and the sampled stations (Station PParanaguá and Station A - Antonina).

significantly to the transport of iron, timber, fertiliser, and frozen products (LANA et al., 2001).

The climate is classified as subtropical humid mesothermic and the annual mean precipitation is of $2000 \mathrm{~mm}$. There are two seasons: (i) a dry one from April to September and (ii) a rainy one between October and March. The rainfall during the latter is, on average, more than three times that of the former (LANA et al., 2001). The hydrodynamic conditions driven by tidal forcing and river runoff vary between the seasons. The mean tidal range is $2.2 \mathrm{~m}$, with a tidal intrusion of $12.6 \mathrm{~km}$ and amplitudes increasing towards the head of the PEC. The system is partially mixed with a residence time of 3.49 days and a mean fresh water runoff of up to $200 \mathrm{~m}$.

The suspended particulate material peaks in the surface water have two main sources: the drainage runoff during high-precipitation events and the Maximum Turbidity Zone (MTZ) lying between Teixeira's Island and the Port of Paranaguá cross section. Surface sediments in the PEC range from medium silt to poorly selected fine sands and in the inner areas mud. In the vicinity of Paranaguá Port (near Station P) the surface sediment is mainly composed of fine silt. In Antonina Bay, the silt fraction is predominant, except in the river mouths, where sand is the principal sediment component (ANGULO et al., 2006)

The water sampling was undertaken in two anchor sections: station A, located between Teixeira Island and the opposite shore and station P located in front of Paranaguá Port. Station A receives considerable fluvial discharges mainly from the Cachoeira and Nhundiaquara rivers, whereas the region around Station $\mathrm{P}$ receives the Cotinga Sub-estuary rivers, the main ones being the Itibere, the Guaraguaçu and the Maciel.

\section{SAMPLING PROCEDURES AND ANALYTICAL METHODS}

Samples were collected under different riverine conditions, during a low rainfall period (March 21 st 2011 ) and after a flood event (June 14 $\left.{ }^{\text {th }}, 2011\right)$. The sampling was carried out every two hours, simultaneously at the two anchor stations, through a complete tidal cycle (13 h) of spring tides. A total of 21 samples were taken in each section, thus providing a total of 42 samples per sampling period.

Water samples were collected at each station using a 6 L Niskin bottle at the surface, in the middle and at the bottom of the water column $(0.5,5.0$ and $10.0 \mathrm{~m}$, at station A and $0.5,9.0$ and $18.0 \mathrm{~m}$ at station $\mathrm{P}$, respectively). Samples were placed in pre-cleaned plastic bottles. The temperature and salinity data were determined hourly in situ with a CTD seabird probe, and the $\mathrm{pH}$ and DO (dissolved oxygen) were analysed after the surveys.

Approximately $0.5 \mathrm{~L}$ of water samples were filtered with $0.45 \mu \mathrm{m}$ Millipore-MF filters (particulate fraction). 
The filtered fraction (dissolved phase) was acidified with $\mathrm{HCl}(10 \%)$ to a $\mathrm{pH}<1.5$ and stored at $4^{\circ} \mathrm{C}$.

The metal extraction was performed following the aqua regia procedure according to that recommended by the International Organization for Standardization (ISO, 1995). Briefly, the filters were placed in acid-cleaned Teflon beakers and digested with $20 \mathrm{ml}-1$ of $\mathrm{HCl}: \mathrm{HNO} 3$ (3:1) mixture on a hotplate at $90{ }^{\circ} \mathrm{C}$ for two hours, in an open system. The suspension obtained was then filtered and diluted up to $25 \mathrm{ml}-1$ with $0.17 \mathrm{M} \mathrm{HNO}_{3}$ and stored at $4^{\circ} \mathrm{C}$ until analysis.

The elements were determined using inductively coupled plasma-optical emission spectrometry (ICPOES). The element yttrium (Y) was used as an internal standard to correct matrix effects specially related to the salinity effect. Blanks were included in each batch of analyses. The analytical precision expressed as a coefficient of variance is $<10 \%$ for all the metals, based on replicate analysis.

Certified reference materials SS-2 soil standards of SCP Science and NIST 1643e for water (National Institute of Standards and Technology) were analyzed to verify the accuracy of the methodology. The average results for the Certified Reference materials were within the upper and lower 98\% confidence interval reference values (Table 1).

The detection method limits (MDL) for each replicate were $\mathrm{Ni}$ and $\mathrm{Fe}: 0.1 \mu \mathrm{g} \mathrm{l}^{-1}, \mathrm{~Pb}$ and $\mathrm{Mn}: 0.2 \mu \mathrm{g} \mathrm{l}^{-1}$ and $\mathrm{Cu}$ : $0.4 \mu \mathrm{g} \mathrm{l}^{-1}$.

\section{STATISTICS}

Prior to further statistical analyses, all data were $\log (\mathrm{x}+1)$ transformed.

Multivariate analyses were made on Euclidiean dissimilarity matrices. Differences in metal concentrations were analyzed using a one factor analysis of similarity (ANOSIM). For this each station was considered a group, as follows: A1 and P1 (Antonina and Paranaguá, respectively) after the flood event and A2 and P2 during the dry period.

In order to determine which element most contributed to any dissimilarity or similarity between the pre-defined groups, a similarities of percentages (SIMPER) analysis was performed. All analyses were run using the PRIMER v6 software (Plymouth Marine Laboratories) (CLARKE; GORLEY, 2006).

Pearson correlations were obtained using $\mathrm{R}$ software package (R Development Core Team, 2010).

\section{RESULTS AND DISCUSSION}

\section{DISTRIBUTION OF SUSPENDED PARTICULATE MATTER}

\section{AND ENVIRONMENTAL PARAMETERS}

According to a 30-year data set, this was the most extreme event recorded in the PEC, as shown in Figure 2. The Cachoeira and Nhundiaquara rivers attained respective flows of 89 and $37 \mathrm{~m}^{3} \mathrm{~s}^{-1}$, which influenced the distribution of physical-chemical parameters and metal distribution at both Stations. Table 2 summarizes the physical-chemical parameters and metal concentrations in the dissolved and particulate phase.

SPM loading reflected the excessive increase in the rainfall and subsequent soil leaching, the increase in drainage basin runoff and the consequent inflow from rivers decreased the salinity values and led to an increment in SPM levels, reaching $541 \mathrm{mg} \mathrm{l}^{-1}$ at Station A and 300 $\mathrm{mg} \mathrm{l}^{-1}$ at Station P. These concentrations were extremely high compared to the average values of $130 \mathrm{mg} \mathrm{l}^{-1}$ found in previous studies in the PEC system (SANTOS et al., 2009; MANTOVANELI et al., 2004; LANA et al., 2001). These concentrations were higher than those found in the Gulf of Thailand (CENSI et al., 2006) and below the concentrations found in the Severn estuary, England,

Table 1. Comparison of metal concentrations in the contaminated soil reference material (SS1) (ug $\left.\mathrm{kg}^{-1}\right)$ and the water reference material (NIST 1643e) $\left(\mu \mathrm{g} \mathrm{l}^{-1}\right)$.

\begin{tabular}{lcccccc}
\hline Materials & $\mathrm{Fe}$ & $\mathrm{Al}$ & $\mathrm{Mn}$ & $\mathrm{Cu}$ & $\mathrm{Ni}$ & $\mathrm{Pb}$ \\
\hline SS1 & $19 \pm 2.0$ & $12 \pm 1.4$ & $433 \pm 33$ & $182 \pm 12$ & $50 \pm 5.6$ & $116 \pm 14$ \\
Mean & $20 \pm 0.4$ & $12 \pm 1.6$ & $463 \pm 1.2$ & $191 \pm 3$ & $54 \pm 2$ & $129 \pm 3$ \\
Recovery (\%) & 95.2 & $93 \%$ & $99.3 \%$ & 98.4 & $97.1 \%$ & $99.2 \%$ \\
NIST 1643e & $99.31 \pm 0.007$ & $138.1 \pm 0.030$ & $38.74 \pm 0.006$ & $22.78 \pm 0.004$ & $62.85 \pm 0.006$ & $19.67 \pm 0.003$ \\
Mean & $98.1 \pm 1.4$ & $141.8 \pm 8.6$ & $38.97 \pm 0.45$ & $22.76 \pm 0.31$ & $62.41 \pm 0.69$ & $19.63 \pm 0.21$ \\
Recovery (\%) & 99.8 & 91.8 & 98.3 & 98.7 & 99.6 & 99.2 \\
\hline
\end{tabular}




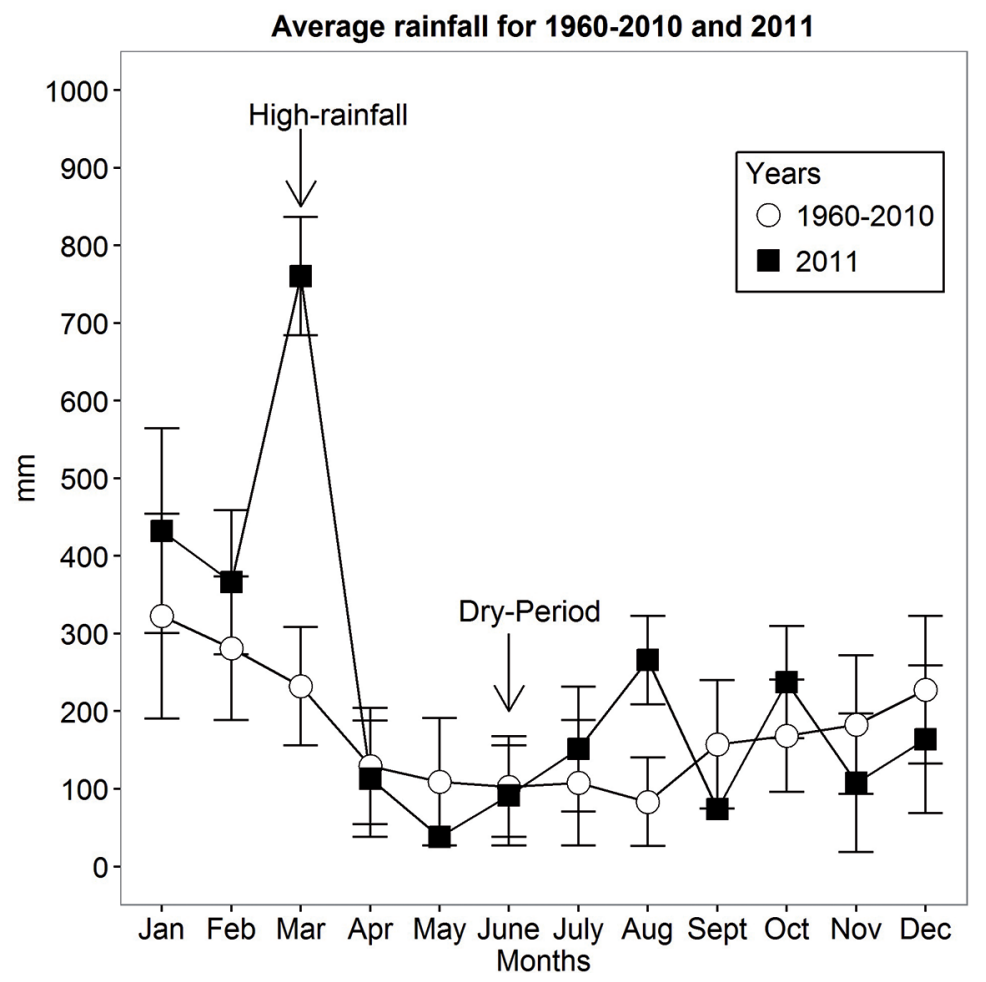

Figure 2. Monthly average total precipitation in Morretes from 1960 to 2010 and 2011 (mm). Arrows pointing to the sampled periods (high rainfall and dry-period).

Table 2. The average ( \pm standard deviation) of master variables and the metal concentrations in the dissolved and particulate phase during the two sampled periods.

\begin{tabular}{|c|c|c|c|c|}
\hline \multirow[b]{2}{*}{ Variables } & \multicolumn{2}{|c|}{ Flood episode $n=42$} & \multicolumn{2}{|c|}{ Low rainfall $n=42$} \\
\hline & Station $\mathrm{P}$ & Station A & Station $\mathrm{P}$ & Station A \\
\hline Salinity & $20.2 \pm 2.18$ & $12 \pm 3.31$ & $29.1 \pm 0.72$ & $25.4 \pm 1.86$ \\
\hline $\mathrm{pH}$ & $7.9 \pm 0.18$ & $7.3 \pm 0.14$ & $7.7 \pm 0.08$ & $7.5 \pm 0.12$ \\
\hline $\mathrm{SPM}\left(\mathrm{mg} \mathrm{l}^{-1}\right)$ & $87.3 \pm 93.55$ & $190.1 \pm 33.42$ & $33.3 \pm 33.42$ & $15.4 \pm 9.96$ \\
\hline DO $(\%)$ & $69.1 \pm 8.3$ & $54.8 \pm 6.1$ & $86.2 \pm 5.6$ & $87.3 \pm 6.4$ \\
\hline Elements & \multicolumn{4}{|c|}{ Dissolved phase } \\
\hline $\mathrm{Al}\left(\mu \mathrm{g} \mathrm{l}^{-1}\right)$ & $108.3 \pm 79.1$ & $89.3 \pm 30.1$ & $87.7 \pm 16.3$ & $101.7 \pm 22.1$ \\
\hline $\mathrm{Cu}\left(\mu \mathrm{g} \mathrm{l}^{-1}\right)$ & $1.5 \pm 0.6$ & $1.3 \pm 0.5$ & $3.2 \pm 0.9$ & $1.9 \pm 0.4$ \\
\hline $\mathrm{Fe}\left(\mu \mathrm{g}^{-1}\right)$ & $19.3 \pm 24.9$ & $13.9 \pm 9.9$ & $15.1 \pm 8.3$ & $10.3 \pm 9.7$ \\
\hline $\operatorname{Mn}\left(\mu \mathrm{g}^{-1}\right)$ & $6.4 \pm 10.6$ & $201.4 \pm 91.6$ & $15.5 \pm 1.5$ & $6.6 \pm 4.1$ \\
\hline Elements & \multicolumn{4}{|c|}{ Particulate phase } \\
\hline $\mathrm{Al}\left(\mathrm{g} \mathrm{kg}^{-1}\right)$ & $6.72 \pm 4.00$ & $3.92 \pm 4.58$ & $3.77 \pm 3.09$ & $4.54 \pm 1.48$ \\
\hline $\mathrm{Fe}\left(\mathrm{g} \mathrm{kg}^{-1}\right)$ & $6.08 \pm 3.37$ & $7.67 \pm 2.95$ & $4.2 \pm 3.55$ & $4.04 \pm 1.34$ \\
\hline $\operatorname{Mn}\left(\mathrm{g} \mathrm{kg}^{-1}\right)$ & $0.14 \pm 0.08$ & $0.06 \pm 0.02$ & $0.12 \pm 0.09$ & $0.09 \pm 0.03$ \\
\hline $\mathrm{Cu}\left(\mu \mathrm{g} \mathrm{g}^{-1}\right)$ & $4.23 \pm 1.91$ & $5.93 \pm 2.41$ & $2.76 \pm 1.64$ & $5.44 \pm 2.13$ \\
\hline $\mathrm{Ni}\left(\mu \mathrm{g} \mathrm{g}^{-1}\right)$ & $3.73 \pm 1.82$ & $3.46 \pm 1.24$ & $4.43 \pm 2.9$ & $2.52 \pm 0.82$ \\
\hline $\mathrm{Pb}\left(\mu \mathrm{g} \mathrm{g}^{-1}\right)$ & $6.65 \pm 3.36$ & $7.59 \pm 2.98$ & $4.44 \pm 3.51$ & $5.18 \pm 2.45$ \\
\hline
\end{tabular}


subject to a macrotidal regime (average of $1500 \mathrm{mg} \mathrm{l}^{-1}$; JONAS; MILLWARD, 2010).

The physical-chemical variables were plotted against salinity (Figure 3 ). The $\mathrm{pH}$ values after the flood were lower at Station A $(7.3 \pm 0.15)$ than Station P $(7.97 \pm 0.17)$, due to Station A's proximity to the main rivers. In general, the $\mathrm{pH}$ decreased throughout the sampling, reaching 7.05 in the bottom water. Following the same trend, oxygen saturations were higher at Station P $(69.1 \pm 8.3)$ than at Station A $(54.8 \pm 6.1)$, decreasing along with increasing SPM concentrations.

During the low rainfall period, the flow of the Cachoeira and Nhundiaquara rivers decreased substantially, respectively, to $32.73 \mathrm{~m}^{3} \mathrm{~s}^{-1}$ and $5.75 \mathrm{~m}^{3} \mathrm{~s}^{-1}$. Salinity rose from 21 to 30, typical of fluvio-estuarine zones and marine water and as a result DO concentrations increased to similar concentrations at both Stations (average of 86.5\%) (Table 2). SPM contents were lower, with concentrations within the PEC average, ranging from 6.8 - $132.2 \mathrm{mg} \mathrm{l}^{-1}$ at Station $\mathrm{P}$ and between $5.24-43.3 \mathrm{mg} \mathrm{l}^{-1}$ at Station A.

The decrease in oxygen levels after the flood reached $44.6 \%$ saturation at Station $\mathrm{A}$, whereas during the dry period values were above $70 \%$ at both Stations. Hence, the hydrological changes resulting in freshwater input from excessive rain can influence the nutrient and organic matter discharges to coastal systems, and hence influence the oxygen balance decreasing the oxygen levels after the flood event (MIDDELBURG et al., 2009; TURNER et al., 2008).

The concentrations of six particulate metals, Al, Fe, $\mathrm{Mn}, \mathrm{Cu}, \mathrm{Ni}$ and $\mathrm{Pb}$, were analyzed. The levels of dissolved $\mathrm{Pb}$ and $\mathrm{Ni}$ were below the limit of detection, therefore only the distributions of dissolved $\mathrm{Al}, \mathrm{Cu}, \mathrm{Fe}$ and $\mathrm{Mn}$ are discussed in the present article.

\section{DiSSOLVED METALS}

The ANOSIM results (Table 3) were highly significant $(p=0.001)$, showing a significant dissimilarity at Station A between the two periods sampled $(\mathrm{R}=1.0)$ and between the sections, $(\mathrm{R}=0.9)$ after the flood event. Whereas during the dry period (A2 x P2) there was a high degree of similarity between the stations sampled $(\mathrm{R}=0.3)$, station $\mathrm{P}$ did not show any significant differences between the sampled periods $(\mathrm{R}=0.2)$.

SIMPER analyses were undertaken to identify the metals which accounted for the largest part of the differences indicated by the ANOSIM results. Dissolved Mn was, overall, the element that contributed most to the dissimilarities found between the stations after the flood event $(92.6 \%)$ and also for those at Station A in both the sampled periods $(84.9 \%)$, followed by $\mathrm{Fe}(12.2 \%)$.

The results of the statistical analysis are in agreement with the dissolved metals vs salinity plot (Figure 4), on which an increase in the major element ( $\mathrm{Al}, \mathrm{Fe}$ and $\mathrm{Mn}$ )
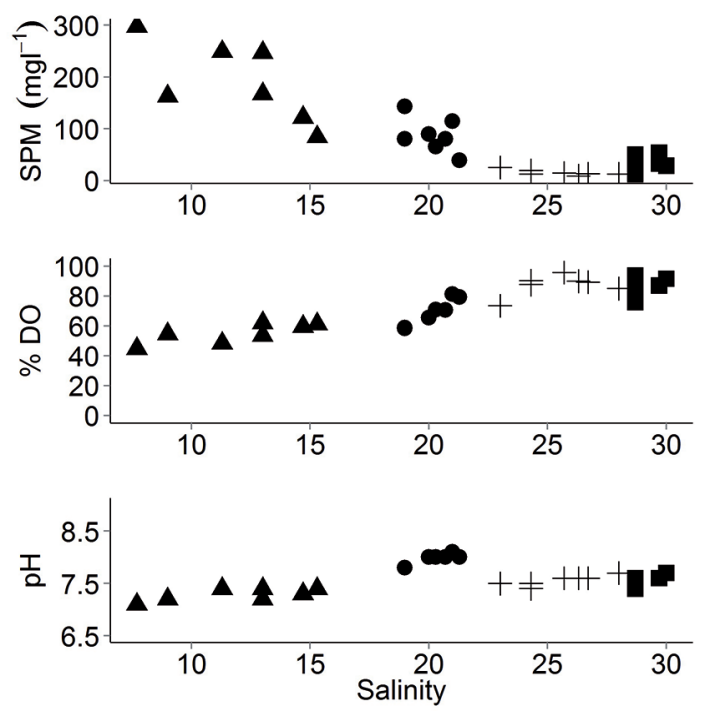

Figure 3. Distributions of SPM $\left(\mathrm{mg} \mathrm{l}^{-1}\right)$, DO saturation (\%) and $\mathrm{pH}$ as a function of salinity. Station A-flood event: black triangle ( $\mathbf{\Delta})$; Station P- flood event: black circle $(\bullet)$; Station A - dry period: cross symbol (+); Station P-dry period: black squares (ם). 
Table 3. Results of ANOSIM analysis for the Stations comparing the two sampled periods.* The closer to 1.0 the values of the significance levels of $\mathrm{R}$, the more significantly different these factors are from each other.

\begin{tabular}{lccc}
\hline Groups & Global test & R Statistic & Significance Level $(\mathrm{p})$ \\
\hline Dissolved metals & & & \\
\hline P1, A1 & 0.607 & $0.9^{*}$ & 0.001 \\
P2, A2 & 0.607 & 0.3 & 0.001 \\
P1, P2 & 0.607 & 0.2 & 0.001 \\
A1, A2 & 0.607 & $1.0^{*}$ & 0.001 \\
\hline Particulate metals & & & \\
\hline P1, A1 & 0.352 & 0.3 & 0.001 \\
P2, A2 & 0.352 & 0.3 & 0.001 \\
P1, P2 & 0.352 & 0.2 & 0.004 \\
A1, A2 & 0.352 & $0.7^{*}$ & 0.001 \\
\hline
\end{tabular}

concentrations can be seen at both stations, except for $\mathrm{Cu}$, after the flood. Generally, concentrations are higher at Station P, except for Mn which exhibited considerably higher concentrations at Station A $103.9 \pm 118.8{\mu \mathrm{gl}^{-1}}^{-1}$ (average and standard deviation).

The manganese concentration at Station A varied from $50-368 \mu \mathrm{g} \cdot \mathrm{l}^{-1}$ pointing to an additional source or sources for this metal (Figure 4). These higher concentrations were found when DO reached $3.09 \mathrm{mgl}^{-1}(\mathrm{r}=0.50, p<0.05)$ and salinity was $14.0(\mathrm{r}=-0.83, p<0.05)$, suggesting that the high fresh water input promoted the decrease in aerobic conditions generating the dissolution of oxyhydroxides.

At Station A sediments are muddy and could, therefore, be easily resuspended, especially during floods, deriving from an organic matter reduction pathway fueled by Mn oxides (REGNIER; WOLLAST, 1993). Hence, another possible source could have been related to the injection of Mn-enriched interstitial water into the water column during periods of surface sediment erosion and advective flows of groundwater. The reduction of Mn (IV) to the more soluble Mn (II) in sediments subject to reducing conditions has been described in various studies (ZHOU et al., 2003; SANDERS et al. 2012).

After release into the water column, dissolved Mn oxidized more slowly and tended to precipitated in the lower estuary, the higher particulate concentrations at Station P suggesting that aerobic conditions were restored resulting in the precipitation of dissolved phase $\mathrm{Mn}$ in the form of oxy-hydroxides or its association with organic material (MCMANUS et al., 2012).
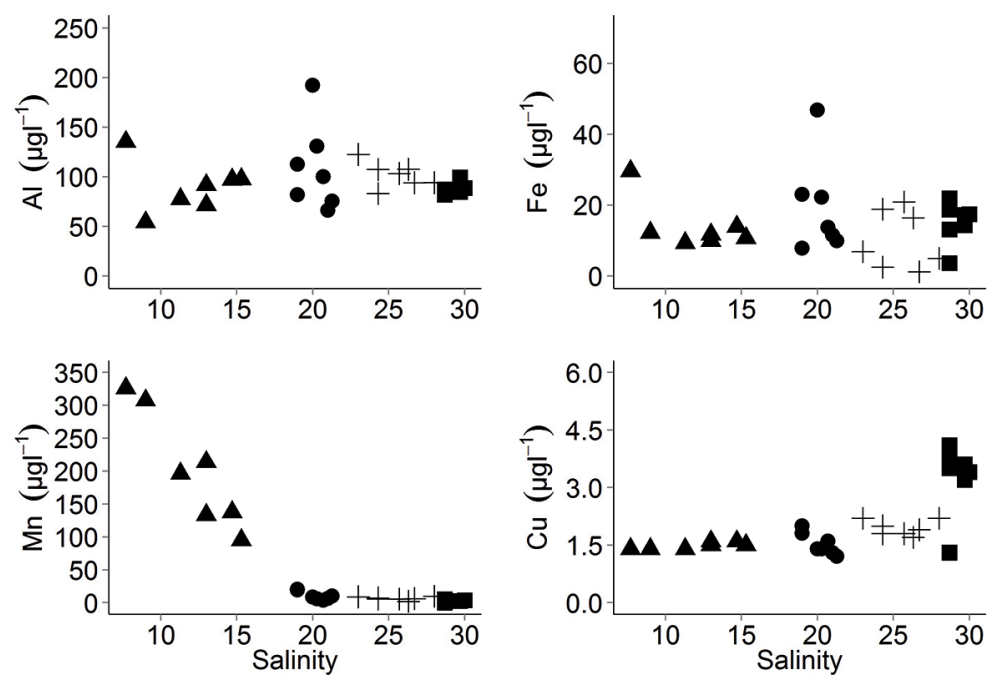

Figure 4. Distributions of dissolved $\mathrm{Al}, \mathrm{Fe}, \mathrm{Mn}$ and $\mathrm{Cu}\left(\mu \mathrm{g} \mathrm{l}^{-1}\right)$ as a function of salinity. Station A-flood event: black triangle $(\boldsymbol{\Delta})$; Station P- flood event: black circle $(\bullet)$; Station A - dry period: cross symbol (+); Station P-dry period: black squares (- $\mathbf{})$. 


\section{PARTiCUlate METALS}

The ANOSIM results were significant $(p=0.001)$, the only dissimilarity $(\mathrm{R}=0.7)$ was found for station $\mathrm{A}$ between the two sampled periods (Table 3). SIMPER analysis pointed to the contribution of $\mathrm{Al}(57.7 \%)$ and particulate Fe $(13.0 \%)$ for the differences between the periods sampled at this station.

Particulate metals were plotted against salinity (Figure 5). After the flood, the distribution of particulate metals at the Stations was similar and could be related to the absence of any sharp trend, for instance $\mathrm{Fe}, \mathrm{Cu}$ and $\mathrm{Pb}$ had higher concentrations at Station A, whereas Al, Mn and Ni were higher at Station P. During the low rainfall period, the elements showed the same trend. The exceptions were the increase in $\mathrm{Al}$ at Station $\mathrm{A}$ and in $\mathrm{Fe}$ at Station P.

Even though the highest $\mathrm{Al}$ content was found at Station $\mathrm{P}$, the concentrations varied greatly at both Stations (from 0.2 to $12.7 \mathrm{~g} \mathrm{~kg}^{-1}$ at Station A and from 2.4 to $18.2 \mathrm{~g}$ $\mathrm{kg}^{-1}$ at Station P), reflecting the input of freshwater into the system - leaching it, and the runoff of more acidified soils resulting in water more greatly enriched in mobilised metals (REGNIER; WOLLAST, 1993). Besides that, the increase of dissolved $\mathrm{Al}$ at Station $\mathrm{P}$ along with increased salinity suggested also that the mechanism responsible was removal by adsorption onto SPM and/or salt-induced flocculation (MORRIS et al., 1986). All the particulate metals showed a strong correlation with $\mathrm{Al}$ implying that they were subject to the same processes and/or that they had the same sources (supplementary material).

During the dry period, the behavior of $\mathrm{Al}$ was related to its adsorption onto SPM. The highest concentrations in particulate form were found at Station P $\left(10.4 \mathrm{~g} \mathrm{~kg}^{-1}\right)$, as well as the lowest concentrations in its dissolved form. Conversely, at Station P the trend was the opposite with an increase in the dissolved phase and a decrease in its particulate form. Therefore, dissolved aluminium seems to be highly reactive in the PEC undergoing a net removal at Station A (upper estuary) and a net input at Station P (midestuary). This behavior of Al has been described for other estuaries too (WANG et al., 2015).

The particulate metal concentrations found in the PEC were compared to those reported for other estuaries and coastal zones around the world (Table 4). Contents were lower than in highly polluted places such as the Mar Chiquita Lagoon, Argentina (BELTRAME et al., 2009) and the Dakar Coast (DIOP et al. 2014); moderately polluted estuaries like the Scheldt Estuary (ZWOLSMAN; VAN ECK, 1999) and the Changjiang Estuary, China (HSU; LIN, 1998), and comparable to well preserved systems such as Jaguaripe Estuary, Bay of Santos, Brazil (HATJE et al., 2012) and Corcunbion Sound, Iberian Peninsula (PREGO et al., 2013).

On both sampling events the strong correlation of particulate metals with SPM (results shown in supplementary material) implied that SPM was the main
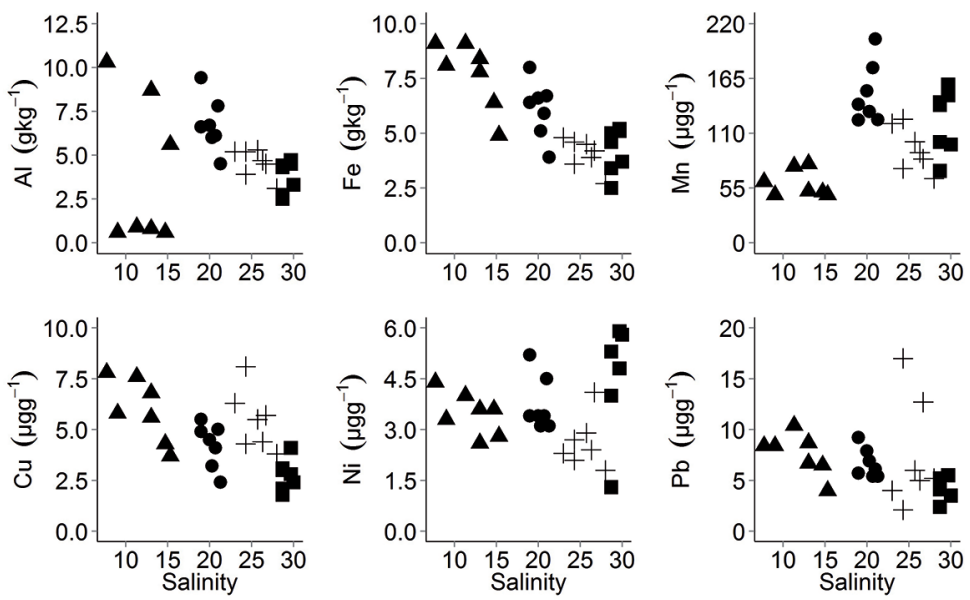

Figure 5. Distributions of major elements: $\mathrm{Al}$ and $\mathrm{Fe}\left(\mathrm{g} \mathrm{kg}^{-1}\right)$ and particulate metals: $\mathrm{Mn}, \mathrm{Cu}$, $\mathrm{Ni}$ and $\mathrm{Pb}\left(\mu \mathrm{g} \mathrm{g}^{-1}\right)$ as a function of salinity. Station A-flood event: black triangle $(\boldsymbol{\Delta})$; Station P- flood event: black circle (•); Station A - dry period: cross symbol (+); Station P-dry period: black squares (घ) 
Table 4. Particulate metal concentrations in PEC and other estuaries elsewhere. Reference data are given as range data or the average values \pm standard deviation $\left(\mu \mathrm{g} \mathrm{g}^{-1}\right)$; nd $=$ non-detectables

\begin{tabular}{lcccc}
\hline Estuary & $\mathrm{Cu}$ & $\mathrm{Pb}$ & $\mathrm{Ni}$ & References \\
\hline PEC & $1.1-12.1$ & $\mathrm{nd}-12.1$ & $0.5-11.1$ & This study \\
Corcubion Sound & $23.0 \pm 7.0$ & - & $12.0 \pm 7.0$ & PREGO et al., 2013 \\
Mersey estuary & $26 \pm 12.0$ & $93.1 \pm 23.2$ & $22.2 \pm 19.9$ & MARTINO et al., 2002 \\
Yellow river estuary & $26.1-37.8$ & $28.6-36.7$ & $33.3-40.6$ & GAO et al., 2015 \\
Jaguaripe (Bay of Santos) & $4.25-15.2$ & $10.7-34.5$ & $5.64-19.6$ & HATJE; BARROS, 2012 \\
Changjiang Estuary & $311 \pm 203$ & $70 \pm 31$ & $61 \pm 36$ & HSU; LIU, 2010 \\
Yangtze estuary & $73 \pm 3.0$ & $59 \pm 17$ & $56 \pm 5.0$ & KOSHIKAWA et al., 2007 \\
Chinese rivers & $18-54.9$ & $35-82$ & $20-61.8$ & ZHANG; LIU, 2002 \\
Scheldt estuary & $10-288$ & $12-279$ & $3-36$ & ZWOLSMAN; VAN ECK, 1999 \\
Dakar Coast & $2130-7290$ & $470-3870$ & $1030-306$ & DIOP et al., 2014 \\
Mar Chiquita Lagoon & nd -22921.37 & $\mathrm{nd}-345.84$ & nd -16327.91 & BELTRAME et al., 2009 \\
Somborobom Bay & $87.1 \pm 84.1$ & - & $75.7 \pm 68.9$ & TATONE et al., 2015 \\
\hline
\end{tabular}

carrier of these elements and that physical processes such as tidal action significantly increased the concentration of SPM, and played an important role in the cycling of the trace elements in the PEC. The strong correlation between SPM and particulate metals is consistent with the findings of other studies (MUNGSKAARD; PARRY, 2001; BENOIT et al., 1994). The only exception was found at Station P after the flood event, (DUINKER, 1983) suggesting that the relative contribution of permanently suspended fraction to total suspended matter is larger at low than at high suspended matter concentrations and that larger/denser particles dominate at high concentrations. The absence of correlation with SPM could, therefore, be due to the intensification of the current after the flood and the presence of SPM with greater particle surface area.

Moreover, at this station particulate metals showed a close correlation with Fe and Mn suggesting that the SPM input might also be determined primarily by the presence of $\mathrm{Fe}$ and $\mathrm{Mn}$ oxides associated with organic material (DUINKER, 1983). Where the concentrations of colloids are higher with Fe-colloids (MUNKSGAARD; PARRY, 2001). This Station is located near the Sub-Cotinga Estuary; mangrove forests occur throughout the area, accounting for most of the OM that reaches this site and which may be particularly enhanced by the input of nutrients from the rivers, primarily during the rainy season (SÁ et al., 2015). ABREU-MOTA et al. (2014) found high concentrations of sterols related to OM inputs in sediments of the Cotinga Sub-Estuary; the presence of colloidal material in Paranaguá Bay has also been described by DOS ANJOS et al. (2012).

Organic matter has not been determined in this study, hence these assumptions are based only on the metal concentrations. Further investigations to assess the role of organic matter and metals in the PEC precisely are required.

\section{PARTITION CoefFicient}

The partition coefficient $\left(\log 10 \mathrm{~K}_{\mathrm{D}}\right)$ indicates the affinity of an element for the solid phase and its tendency to be carried by particulate material. The partitioning between the dissolved and particulate phases continues to be the parameter most generally used to describe the critical partition of the trace elements between the filtrate and the precipitate in aquatic environments (ZHOU et al., 2003; POKROVSKY; SCHOTT, 2002; BENOIT; ROZAN, 1999). In this study, this coefficient was arrived at by calculating the partition coefficients, $K_{D}$, defined as follows:

$$
\begin{array}{r}
\mathrm{K}_{\mathrm{D}}=\left[\mathrm{M}_{\mathrm{PART}}\right] \\
{\left[\mathrm{M}_{\mathrm{DISS}}\right]}
\end{array}
$$

where $\mathrm{M}_{\text {PART }}$ is the metal concentration in the particles ( $\mathrm{g}$ $\mathrm{kg}^{-1}$ for major metals and ug $\mathrm{g}^{-1}$ for trace metals) and $\mathrm{M}_{\text {DISs }}$ is the metal concentration in the filter-passing fraction $\left(\mathrm{ug}^{-1}\right)$.

The $\log 10 \mathrm{~K}_{\mathrm{D}} \mathrm{s}$ for each dissolved metal were plotted as a function of SPM and salinity (Figure 6 and Figure 7). The $\mathrm{K}_{\mathrm{D}} \mathrm{s}$ decreased according to the sequence $\mathrm{Fe}>\mathrm{Al}>\mathrm{Mn}>$ $\mathrm{Cu}$. Generally, the results showed Fe as having the highest affinity for the solid phase and $\mathrm{Cu}$ for the dissolved phase. The $K_{D}$ values found in this study fell within the range of values calculated for the Severn Estuary and Bristol Channel (JONAS; MILLWARD, 2010); Six Estuaries in Texas (BENOIT et al., 1994) and the Gulf of Thailand (CENSI et al., 2006).

Elevated SPM loadings not only influence particle composition but may also be important in determining partitioning behavior (Figure 6). After the flood, $\mathrm{K}_{\mathrm{D}}$ 

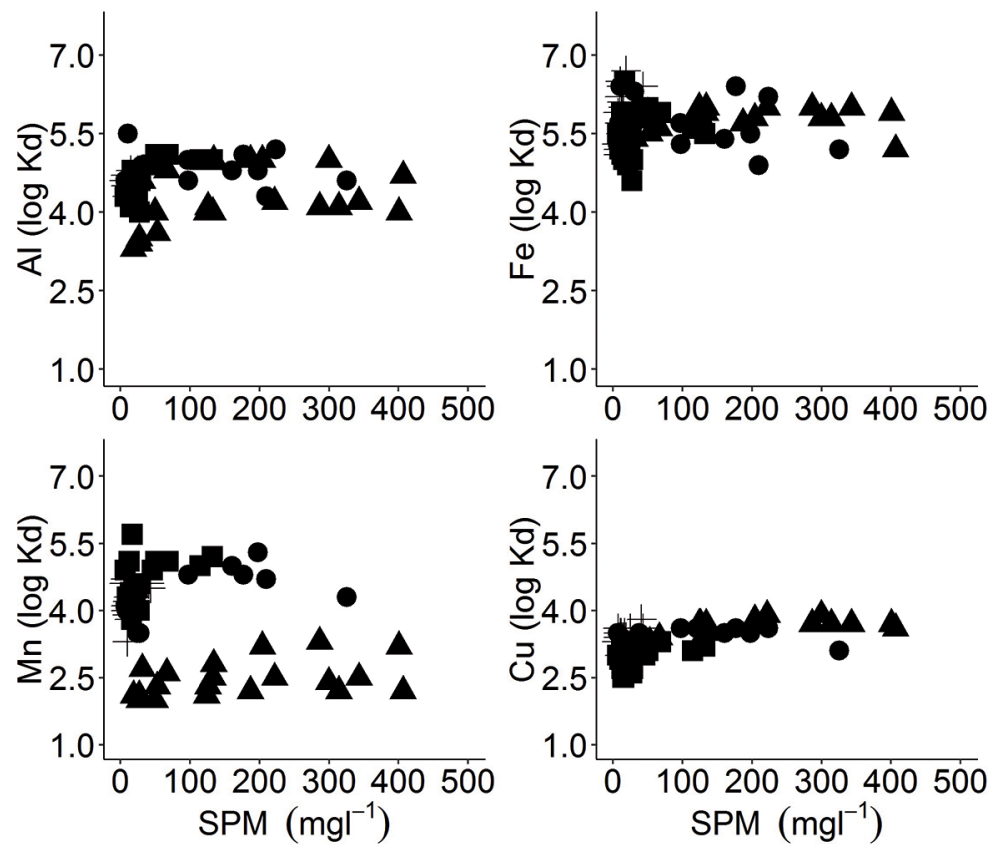

Figure 6. $\log 10 \mathrm{~K}_{\mathrm{D}}$ as a function of SPM $\left(\mathrm{mg} \mathrm{l}^{-1}\right)$. Station A-flood event: black triangle $(\boldsymbol{\Delta})$; Station P- flood event: black circle $(\bullet)$; Station A - dry period: cross symbol $(+)$; Station P-dry period: black squares ( $\mathbf{\square})$.
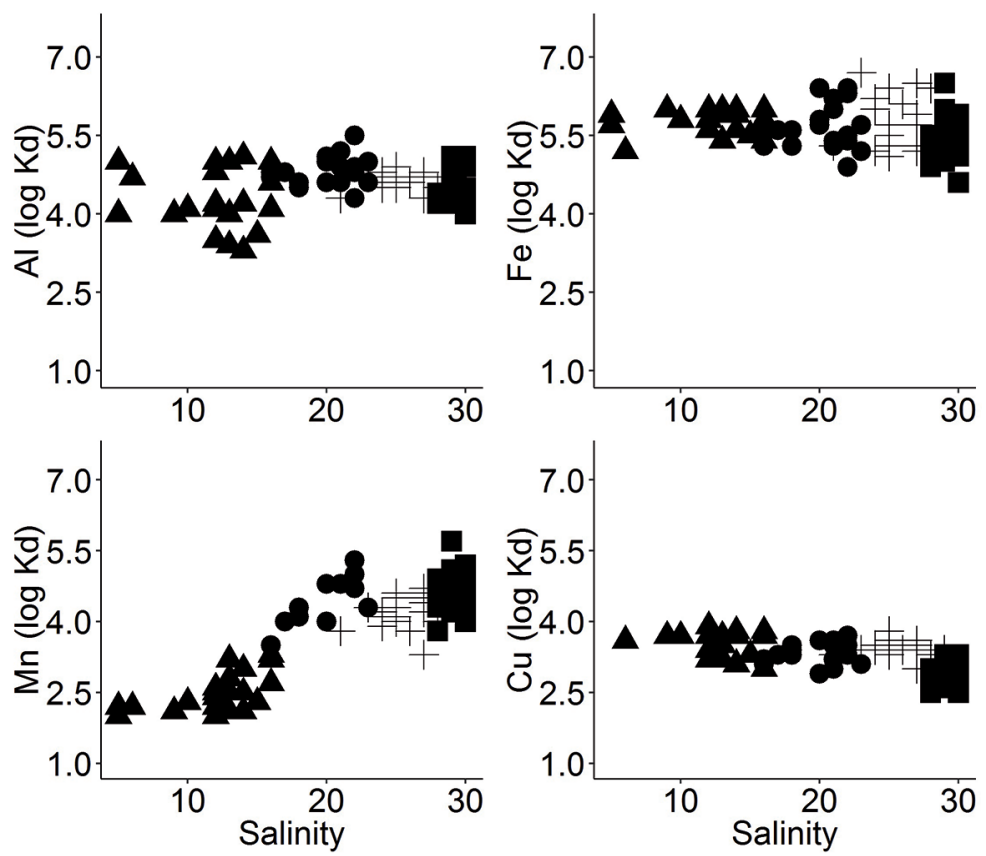

Figure 7. $\log 10 \mathrm{~K}_{\mathrm{D}}$ as a function of salinity. Station A-flood event: black triangle ( $\mathbf{\Delta}$ ); Station P- flood event: black circle $(\bullet)$; Station A - dry period: cross symbol (+); Station P-dry period: black squares ( $\mathbf{\square})$. 
increased by up to $100 \mathrm{mg} \mathrm{l}^{-1}$ whereas during the low rainfall period it was below $50 \mathrm{mg} \mathrm{l}^{-1}$. Beyond this limit, $\mathrm{K}_{\mathrm{D}}$ values were constant, suggesting that metals were strongly bounded to the SPM up to a certain level. Such a relationship may be explained by the relative enrichment of metals in SPM at low SPM concentrations, beyond a certain limit the concentrations remained unchanged due to a relative depletion of metals in SPM at high SPM concentrations (TURNER, 1996).

As has been mentioned above, dissolved Mn presented extremely high concentrations at Station A after the flood event and as a result the $K_{D}$ values for this element presented a high affinity for the dissolved phase. This process suggested that significant interactions involving dissolved manganese were occurring at the limit of salt intrusion (MORRIS et al., 1982) at Station A due to the sharp decrease in salinity (Figure 7). Moreover, this element is redox-sensitive and is relatively mobile in marine environments, therefore the increase in salinity and DO concentrations at Station $\mathrm{P}$ allowed oxidative precipitation of dissolved Mn (II) to precede increasing $\mathrm{K}_{\mathrm{D}}$ values.

Station $\mathrm{P}$ showed the lowest $\mathrm{KD}$ values for $\mathrm{Cu}$ at both samplings; this element's speciation is usually related to the organic fraction of sediments (DUARTE; CAÇADOR, 2012; BENOIT; ROZAN, 1999) and its main source is the contribution of colloidal fractions composed of organic and inorganic complexes of $\mathrm{Cu}$ due to the close association between colloidal $\mathrm{Fe}$ and $\mathrm{Al}$ (ZAGO et al., 2002). DOS ANJOS et al. (2012) found organic compounds associated with arsenic dissolved in the PEC, which could corroborate these assumptions, however in this study organic compounds have not been analysed.

Dissolved $\mathrm{Cu}$ levels (1.1- $\left.4.4 \mathrm{ugl}^{-1}\right)$ were similar to the ones found in estuaries subject to some source of pollution, as for instance the Severn Estuary (JONAS; MILLWARD, 2010), the Adriatic Sea (ACCORNERO et al., 2004) and Port Jackson Estuary (HATJE et al., 2003) and higher than those of well preserved systems such as North Biscay Bay (WAELES et al., 2004) and Northern Australia (MUNKSGAARD; PARRY, 2001).

\section{ENRICHMENT FACTOR}

The enrichment factor was calculated using the abundance of metals in the Earth's crust. Since no data exist regarding background concentrations in the study area, it could be used for purposes of estimation. The suitability of using data relating to the terrestrial crust has been demonstrated in certain other studies (NIENCHESKI et al. (2000) and HSU; LIN (2010). Hence, due to natural variability, the following values were considered $0.5 \leq \mathrm{EF} \leq 2$ derived for natural weathering, while $\mathrm{EF}>2$ was indicative of an anthropogenic contribution or biogenic enrichment processes.
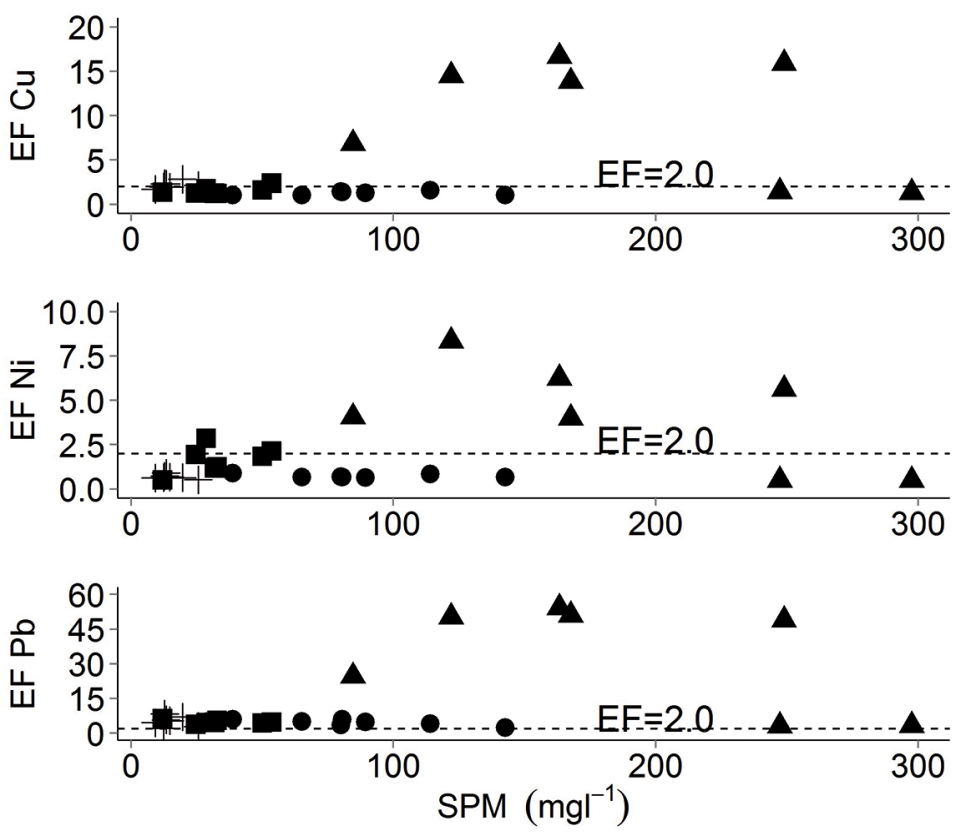

Figure 8. Enrichment Factor of trace metals. Station A-flood event: black triangle ( $\boldsymbol{\Delta})$; Station P- flood event: black circle (•); Station A - dry period: cross symbol (+); Station P-dry period: black squares (ש). 
Trace metals enrichment factor was plotted as a function of SPM (Figure 8).

After the flood event, Station A displayed the highest metal enrichment for all the trace metals studied. The contaminants produced along the PEC are found to be physically transported (e.g. by currents, tides, waves) to internal parts of the estuary, being trapped in the finer sediments of these low-water-energy zones, causing degradation of the sediments (CHUOERI et al., 2009). In addition to that, sediments accumulating in the upper estuary in the inner sections are generally enriched in organic matter under anoxic conditions and mainly composed of silt (CHIFOLLEAU et al., 1994). In Antonina, the soil is primarily used for agricultural activities, such as the cultivation of cassava, rice and bananas, and also by the food industry and the tailrace of the Governador de Souza hydroelectric plant. Altogether, these factors contributed to the increase of fine-grain size sediment input and led to the need for dredging activities in order to facilitate shipping access to the port terminal. In this area, high PAH levels were associated with organic matter from terrestrial sources due to the inputs from runoff and harbor/ industrial activities (CARDOSO et al., 2016), whereas the enrichment of metals was related mainly to the presence of Ponta do Felix Terminal Port (CHOUERI et al., 2009), highlighting the importance of hydrodynamic factors such as the reduction in the current flow in the PEC, which aids the deposition of contaminants at the Antonina Station. These results confirm the influence of the heavy rainfall which not only leads to an increase in soil leaching in the area surrounding Antonina, but also to the resuspension of metals trapped in the sediments of the water column.

The influence of flood events in systems around the world calls for different responses according to each system's characteristics. Authors have described a large amount of sediment with low metal concentrations due to the water's short resident time being discharged into estuaries, and this, in its turn, does not favor particles' chemical alteration. Additionally, a low spatial variation in the element composition leading to a dilution effect has been found to be related to an increase in the SPM content with low trace metals. These common trends have been reported for the Tagus Estuary (DUARTE; CAÇADOR, 2012), the Baltic Sea (POHL et al., 2002). and in the Guadiana Estuary (CAETANO et al., 2006). In these systems, a combination of factors affecting the water's chemical characteristics, along with a decrease in the estuarine water residence time, has turned the respective floods into events that have concealed estuarine contamination.

On the other hand, in the Lot river Estuary (COYNEL et al., 2007), the authors found an increase in metal concentrations during distinct key stages of the flood, attributed to successive dominance of different water masses transporting material from different sources (e.g. industrial point source, bed sediment from reservoirs, plain erosion), as a result of successive dominance by sources from downstream to upstream. WANG et al. (2015) conducted a study after the largest flood peak period in the Changjiang Estuary (China) and found a dilution effect only in the immediately offshore area of the estuary, with a high enrichment of anthropogenic metals related to SPM adsorption of dissolved metals.

In this study, despite the low metal concentrations, the enrichment detected after the flood along with the increase of particulate $\mathrm{Fe}$ and $\mathrm{Al}$ showed the influence of the flood in the PEC. At the Antonina station, characteristics such as shallow depth, great fluvial influence and bottom grain size composition may have favored the input and/ or the resuspension of metals, leading to an accumulation of metals in this area. The behavior of the metals in this section was therefore more closely similar to those of the Lot river and the Changjiang estuary flood events described above.

Whereas, on the other hand, at the Paranaguá station, the behavior of the metals was more closely similar to that of the other systems described for the Tagus and Guadiana estuaries (CAETANO et al. 2006) with their increase of SPM with low metal content. This station was located near the PEC's mouth with a high intrusion of water onto the shelf, increasing the dilution effect. This point is, further, located in a zone where an intensification of the tidal currents is caused by the abrupt reduction in the width of the transversal section and by the constriction of the channel (MANTOVANELLI, 1999). These factors might have favored the dilution effect at this station and thus decreased the effect of the flood event.

In brief, urban development (MUIS et al., 2015) in a scenario of climate change (ALFIERI et al., 2015) interacting with the increase in the frequency of flood events worldwide, may lead to an increase in erosion and fluvial discharge and consequently to a potential enrichment of trace elements as was found in the PEC at Antonina station.

An extensive database related to particulate and dissolved metals was built up on the basis of samplings 
taken after a catastrophic flood event in the Paranaguá Estuarine Complex watershed. The main conclusions of this study may be summarized as follows:

- After the extreme rainfall the Stations presented a different response regarding the input of new material coming from the drainage basin. For instance in Antonina the increase in the concentration of particulate metals was followed by a greater enrichment factor related to oxides of Fe and Mn. Whereas at Station P the lower correlation of particulate metals with SPM was probably associated with the presence of the trace metal mobilization from the watershed, either from soil profiles or reworked soil particles.

- Among the dissolved metals studied, Mn showed unique behavior at Station A after the flood, most likely associated with the redox dynamics of the sediments, corroborated by the low oxygen levels, river outflow or pore water injection also pointing to the influence of such different conditions in the drainage basin. Dissolved $\mathrm{Cu}$ presented higher affinity with the dissolved phase in Paranaguá suggesting a predominance of organic complexes.

The results of this study bring out the importance of flooding as regards the transport of material with high metal content into the estuary and adjacent coastal zone, along with all the related changes in water chemistry, especially in SPM input. Therefore, natural and/or manmade riverbed erosion during flooding needs to be taken into consideration in future assessments of the PEC. Further studies are needed to analyse the real influence of continued flood events and also the steady state of PEC so as better to describe the role of metals in particulate or dissolved form in this system.

\section{ACKNOWLEDGEMENTS}

M. Rocha wishes to thank the Coordenation of the Improvement of Higher Level Personnel (Capes) for their scholarship and research grants (Edital Ciencias do Mar, Proc.09-2009). The author would also thank Dr. Mauricio Noernberg for his assistance during the preparation of the sampling design. This study was undertaken as part of a graduate course on Oceanography at the Federal University of Paraná (CGO-UFPR).

\section{REFERENCES}

ABREU-MOTA, M. A.; BARBOZA, C. A.; BÍCEGO, C. M.; MARTINS, C. C. Chemosphere Sedimentary biomarkers along a contamination gradient in a human-impacted subestuary in Southern Brazil: a multi-parameter approach based on spatial and seasonal variability. Chemosphere, v. 103, p. 156-163, 2014.
ACCORNERO, A.; MANFRA, L.; SALLUZZO, A.; MODESTIA, F. Trace metal pollution in surface marine waters: Nearshore concentrations along Apulia and Albania. J. Chem. Ecol., v. 20, n. sup1, p. 195-203, 2004.

ANGULO, R. J.; SOUZA, M. C.; LAMOUR, M. R. Coastal problems induced by dredging activities in the navigation channels of Paranaguá and Sao Francisco do Sul harbour, Southern Brazil. J. Coast. Res., v. 39, p. 1801-1803, 2006.

ALFIERI, L.; FEYEN, L.; DOTTORI, F.; BIANCHI, A. Ensemble flood risk assessment in Europe under high end climate scenarios. Glob. Environ. Chang., v. 35, p. 199-212, 2015.

ANGELI, J. L.; TREVIZANI, T. H.; RIBEIRO, A.; MACHADO, E. C.; FIGUEIRA, R. C.; MARKERT, B.; FRAENZLE, S.; WUENSCHMANN, S. Arsenic and other trace elements in two catfish species from Paranaguá Estuarine Complex, Paraná, Brazil. Environ. Monit. Assess., v. 185, n. 10, p. 83338342, 2013.

BELTRAME, M. O.; DE MARCO, S. G.; MARCOVECCHIO, J. E. Dissolved and particulate heavy metals distribution in coastal lagoons. A case study from Mar Chiquita Lagoon, Argentina. Estuar. Coast. Shelf Sci., v. 85, n. 1, p. 45-56, 2009.

BENOIT, G.; OKTAY-MARSHALL， S. D.; CANTU，A.; HOOD, E. M.; COLEMAN, C. H.; CORAPCIOGLU, M. O.; SANTSCHI, P. H. Partitioning of $\mathrm{Cu}, \mathrm{Pb}, \mathrm{Ag}, \mathrm{Zn}, \mathrm{Fe}, \mathrm{Al}$, and Mn between filter-retained particles, colloids, and solution in six Texas estuarie. Mar. Chem., v. 45, n. 5, p. 307-336, 1994.

BENOIT, G.; ROZAN, T. F. The influence of size distribution on the particle concentration effect and trace metal partitioning in rivers. Geochim. Cosmochim. Acta, v. 63, n. 1, p. 113-127, 1999.

BIATI, A.; KARBASSI, A. R. Flocculation of metals during mixing of Siyahrud River water with Caspian Sea water. Environ. Monit. Assess., v. 184, n. 11, p. 6903-6911, 2012.

CAETANO, M.; VALE, C.; FALCÃO, M. Particulate metal distribution in Guadiana estuary punctuated by flood episodes. Estuar. Coast. Shelf Sci., v. 70, n. 1-2, p. 109-116, 2006.

CARDOSO, F. D.; DAUNER, A. L. L.; MARTINS, C. C. A critical and comparative appraisal of polycyclic aromatic hydrocarbons in sediments and suspended particulate material from a large South American subtropical estuary. Environ. Pollut., v. 214, p. 219-229, 2016.

CENSI, P.; SPOTO, S. E.; SAIANO, F.; SPROVIERI, M.; MAZZOLA, S.; NARDONE, G.; DI GERONIMO, S. I.; PUNTURO, R.; OTTONELLO, D. Heavy metals in coastal water systems. A case study from the northwestern Gulf of Thailand. Chemosphere, v. 64, n. 7, p. 1167-1176, 2006.

CHIFFOLEAU, J. F.; COSSA, D.; AUGER, D.; TRUQUET, I. Trace metal distribution, partition and fluxes in the Seine estuary (France) in low discharge regime. Mar. Chem., v. 47, n. 2, p. 145-158, 1994.

CHOUERI, R. B.; CESAR, A.; TORRES, R. J.; ABESSA, D. M. S.; MORAIS, R. D.; PEREIRA, C. D. S.; NASCIMENTO, M. R. L.; MOZETO, A. A.; RIBA, I.; DELVALLS, T. A. Integrated sediment quality assessment in Paranaguá Estuarine System, Southern Brazil. Ecotoxicol. Environ. Saf., v. 72, n. 7, p. 1824-1831, 2009.

CLARKE, K.; GORLEY, R. PRIMER v6: User Manual/Tutorial. Plymouth: PRIMER-E, 2006.

COYNEL, A.; SCHÄFER, J.; BLANC, G.; BOSSY, C. Scenario of particulate trace metal and metalloid transport during 
a major flood event inferred from transient geochemical signals. Appl. Geochem., v. 22, n. 4, p. 821-836, 2007.

COMBI, T.; TANIGUCHI, S.; FIGUEIRA, R. C.; MAHIQUES, M. M.; MARTINS, C. C. Spatial distribution and historical input of polychlorinated biphenyls (PCBs) and organochlorine pesticides (OCPs) in sediments from a subtropical estuary (Guaratuba Bay, SW Atlantic). Mar. Pollut. Bull., v. 70, n. 1-2, p. 247-252, 2013.

DIOP, C.; DEWAELÉ, D.; DIOP, M.; TOURÉ, A.; CABRAL, M.; CAZIER, F.; FALL, M.; DIOUF, A.; OUDDANE, B. Assessment of contamination, distribution and chemical speciation of trace metals in water column in the Dakar coast and the Saint Louis estuary from Senegal, West Africa. Mar. Pollut. Bull., v. 86, n. 1-2, p. 539-546, 2014.

DOS ANJOS, V. E.; MACHADO, E. C.; GRASSI, M. T. Biogeochemical Behavior of Arsenic Species at Paranaguá Estuarine Complex, Southern Brazil. Aquat. Geochem., v. 18, n. 5, p. 407-420, 2012.

DUARTE, B.; CAÇADOR, I. Particulate metal distribution in Tagus estuary (Portugal) during a flood episode. Mar. Pollut. Bull., v. 64, n. 10, p. 2109-2116, 2012.

DUINKER, J. C. Effects of particle size and density on the transport of metals to the oceans. In: WONG, C. S.; BOYLE, E.; BRULAND, K. W.; BURTON, J. D.; EDWARD, D.; GOLDBERG, E. D. (eds.). Trace metals in sea water. New York: Springer Verlag, 1983. p. 209-226.

GAO, X.; ZHOU, F.; CHEN, C. T. A.; XING, Q. Trace metals in the suspended particulate matter of the Yellow River (Huanghe) Estuary: Concentrations, potential mobility, contamination assessment and the fluxes into the Bohai Sea. Cont. Shelf Res., v. 104, p. 25-36, 2015.

HATJE, V.; APTE, S. C.; HALES, L. T.; BIRCH, G. F. Dissolved trace metal distributions in Port Jackson estuary (Sydney Harbour), Australia. Mar. Pollut. Bull., v. 46, n. 6, p. 719$730,2003$.

HATJE, V.; BARROS, F. Overview of the 20th century impact of trace metal contamination in the estuaries of Todos os Santos Bay: Past, present and future scenarios. Mar. Pollut. Bull., v. 64, n. 11, p. 2603-2614, 2012.

HSU, S. C.; LIN, F. J. Elemental characteristics of surface suspended particulates off the Changjiang estuary during the 1998 flood. J. Mar. Syst., v. 81, n. 4, 323-334, 2010.

ISO. ISO-11466 I. International O for S. Soil quality, Extraction of Trace Elements Soluble in Aqua Regia. Geneva: ISO. 1995, 03:22.

JONAS, P. J. C.; MILLWARD, G. E. Metals and nutrients in the Severn Estuary and Bristol Channel: contemporary inputs and distributions. Mar. Pollut. Bull., v. 61, n. 1-3, p. 52-67, 2010.

KOSHIKAWA, M. K.; TAKAMATSU, T.; TAKADA, J.; ZHU, M.; XU, B.; CHEN, Z.; MURAKAMI, S.; XU, K.; WATANABE, M. Distributions of dissolved and particulate elements in the Yangtze estuary in 1997-2002: background data before the closure of the Three Gorges Dam. Estuar. Coast. Shelf Sci., v. 71, p. 26-36, 2007.

LANA P. C.; MARONE, E.; LOPES, R. M.; MACHADO, E. C. The subtropical estuarine complex Paranaguá Bay, Brazil. In: SEELIGER, U.; KJERFVE, B. (Eds). Coastal Marine Ecosystems of Latin America. Berlin, Heidelberg: Springer Verlag, 2001. p. 131-145.

LI, Y. H.; BURKHARDT, L.; TERAOKA, H. Desorption and coagulation of trace elements during estuarine mixing. Geochim. Cosmochim. Acta, v. 48, n. 10, p. 1879-1884, 1984.
MANTOVANELLI, A., 1999. Caracterizacao da dinamica hídrica e do material particulado em suspensão na Baia de Paranaguá e em sua bacia de drenagem. Master Thesis of Universidade Federal do Parana ,Curitiba, 152 pp.

MANTOVANELLI, A.; MARONE, E.; SILVA, E. T.; LAUTERT, L.F.; KLINGENFUSS, M. S.; PRATA JR., V. P.; NOERNBERG, M. A.; KNOPPERS, B. A.; ANGULO, R. J. Combined tidal velocity and duration asymmetries as a determinant of water transport and residual flow in Paranaguá Bay Estuary. Estuar. Coast. Shelf Sci., v. 59, p. 523-537, 2004.

MARTINO, M.; TURNER, A.; NIMMO, M.; MILLWARD, G. E. Resuspension, reactivity and recycling of trace metals in the Mersey Estuary, UK. Mar. Chem., v. 77, n. 2-3, p. 171186, 2002.

MARTINS, C. C.; BRAUN, J. A. F.; SEYFFERT, B. H.; MACHADO, E. C.; FILLMANN, G. Anthropogenic organic matter inputs indicated by sedimentary fecal steroids in a large South American tropical estuary (Paranaguá estuarine system, Brazil). Mar. Pollut. Bull., v. 60, n. 11, p. 2137-2143, 2010 .

MASSON, M.; BLANC, G.; SCHÄFER, J. Geochemical signals and source contributions to heavy metal $(\mathrm{Cd}, \mathrm{Zn}, \mathrm{Pb}, \mathrm{Cu})$ fluxes into the Gironde Estuary via its major tributaries. Sci. Total Environ., v. 370, n. 7, p. 133-146, 2006.

MCMANUS, J.; BERELSON, W. M.; SEVERMANN, S.; JOHNSON, K. S.; HAMMOND, D. E.; ROY, M.; COALE, K. H. Benthic manganese fluxes along the Oregon-California continental shelf and slope. Cont. Shelf Res., v. 43, p. 71-85, 2012.

MIDDELBURG, J. J.; LEVIN, L. A. Coastal hypoxia and sediment biogeochemistry. Biogeosciences, v. 6, p. 36553706, 2009.

MILly, P. C. D.; WETherald, R. T.; DUNNE, K. A.; DELWORTH, T. L. Increasing risk of great floods in a changing climate. Nature, v. 415, p. 514-517, 2002.

MORRIS, A. W.; BALE, A. J.; HOWLAND, R. J. M. The dynamics of estuarine manganese cycling. Estuar. Coast. Shelf Sci., v. 14, n. 2, p. 175-192, 1982.

MORRIS, A. W.; HOWLAND, R. J. M.; BALE, A. J. Dissolved aluminium in the Tamar Estuary, Southern England. Geochim. Cosmochim. Acta, v. 50, n. 2, p. 189-197, 1986.

MUIS, S.; GÜNERALP, B.; JONGMAN, B.; AERTS, J. C. J. H.; WARD, P. J. Flood risk and adaptation strategies under climate change and urban expansion: A probabilistic analysis using global data. Sci. Total Environ., v. 538, p. 445-457, 2015 .

MUNKSGAARD, N. C.; PARRY, D. L. Trace metals, arsenic and lead isotopes in dissolved and particulate phases of North Australian coastal and estuarine seawater. Mar. Chem., v. 75, n. 3, p. 165-184, 2001.

NIENCHESKI, L. F.; BAUMGARTEN, M. G. Z. Distribution of particulate trace metal in the southern part of the Patos Lagoon estuary. Aquat. Ecosyst. Health Manag., v. 3, n. 4, p. 515-520, 2000.

POHL, C.; HENNINGS, U.; SIEGEL, H.; BACHOR, A. Trace metal impact into the Baltic Sea during the exceptional Oder flood in summer 1997. Mar. Chem., v. 79, n. 3-4, p. 101-111, 2002.

POKROVSKY, O. S.; SCHOTT, J. Iron colloids/organic matter associated transport of major and trace elements in small boreal rivers and their estuaries (NW Russia). Chem. Geol., v. 190, n. 1-4, p. 141-179, 2002. 
POSSATTO, F. E.; SPACH, H. L.; CATTANI, A. P.; LAMOUR, M. R.; SANTOS, L. O.; CORDEIRO, N. M.; BROADHURST, M. K. Marine debris in a World Heritage Listed Brazilian estuary. Mar. Pollut. Bull., v. 91, n. 2, p. 548-553, 2015.

PREGO, R.; SANTOS-ECHEANDÍA, J.; BERNÁRDEZ, P.; COBELO-GARCÍA, A.; VARELA, M. Trace metals in the NE Atlantic coastal zone of Finisterre (Iberian Peninsula): Terrestrial and marine sources and rates of sedimentation. $J$. Mar. Syst., v. 126, p. 69-81, 2013.

REGNIER, P.; WOLLAST, R. Distribution of trace metals in suspended matter of the Scheldt estuary. Mar. Chem., v. 43, n. 1-4, p. 3-19, 1993.

R CORE TEAM. R: A Language and Environment for Statistical Computing. R Foundation for Statistical Computing. Vienna, 2010. Available at: http://www. R-project.org/ (Accessed 2016/01/15).

SÁ, F.; SANDERS, C. J.; PATCHINEELAM, S. R.; MACHADO, E. C.; LOMBARDI, A. T. Arsenic fractionation in estuarine sediments: Does coastal eutrophication influence As behavior? Mar. Pollut. Bull., v. 96, n. 1-2, p. 496-501, 2015.

SANDERS, C. J.; SANTOS, I. R.; BARCELLOS, R.; SILVA FILHO, E. V. Elevated concentrations of dissolved Ba, Fe and $\mathrm{Mn}$ in a mangrove subterranean estuary: Consequence of sea level rise? Cont. Shelf Res., v. 43, p. 86-94, 2012.

SANTOS, D. M.; ARAÚJO, I. P.; MACHADO, E. C.; CARVALHO-FILHO, M. A.; FERNANDEZ, M. A.; MARCHI, M. R.; GODOI, A. F. Organotin compounds in the Paranaguá Estuarine Complex, Paraná, Brazil: evaluation of biological effects, surface sediment, and suspended particulate matter. Mar. Pollut. Bull., v. 58, n. 12, p. 1926-1931, 2009.

SPALDING, M. D.; RUFFO, S.; LACAMBRA, C.; MELIANE, I.; HALE, L. Z.; SHEPARD, C. C.; BECK, M. W. The role of ecosystems in coastal protection: Adapting to climate change and coastal hazards. Ocean Coast. Manag., v. 90, p. 50-57, 2014.

TATONE, L. M.; BILOS, C.; SKORUPKA, C. N.; COLOMBO, J. $\mathrm{C}$. Trace metal behavior along fluvio-marine gradients in the Samborombón Bay, outer Río de la Plata estuary, Argentina. Cont. Shelf Res., v. 96, p. 27-33, 2015.
TURNER, A. Trace-metal partitioning in estuaries: importance of salinity and particle concentration. Mar. Chem., v. 54, n. 1-2, p. 27-39, 1996.

TURNER, R. E.; RABALAIS, N. N.; JUSTIC, D. Gulf of Mexico hypoxia: Alternate states and a legacy. Environ. Sci. Technol., v. 42, n. 7, p. 2323-2327, 2008.

WAELES, M.; RISO, R. D.; MAGUER, J. F.; LE CORRE, P. Distribution and chemical speciation of dissolved cadmium and copper in the Loire estuary and North Biscay continental shelf, France. Estuar. Coast. Shelf Sci., v. 59, n. 1, p. 49-57, 2004.

WANG, Z. W.; REN, J. L.; ZHANG, G. L.; LIU, S. M.; ZHANG, X. Z.; LIU, Z.; ZHANG, J. Behavior of dissolved aluminum in the Huanghe (Yellow River) and its estuary: Impact of human activities and sorption processes. Estuar. Coast. Shelf Sci., v. 153, p. 86-95, 2015.

ZAGO, C.; CAPODAGLIO, G.; BARBANTE, C.; GIANI, M.; MORET, I.; SCARPONI, G.; PAOLO, C. Heavy metal distribution and speciation in the Northern Adriatic Sea. Chem. Ecol., v. 18, n. 1-2, p. 39-51, 2002.

ZHANG, J.\& LIU, C.L., 2002. Riverine Composition and Estuarine Geochemistry of Particulate Metals in China-Weathering Features, Anthropogenic Impact and Chemical Fluxes. Estuar. Coast. Shelf Sci. 54, 1051-1070. doi:10.1006/ecss.2001.0879

ZHANG, S., LU, X., HIGGITT, D., 2008. Recent changes of water discharge and sediment load in the Zhujiang (Pearl River) Basin, China. Glob. Planet. Change 60, 365-380. doi:10.1016/j. gloplacha.2007.04.003

ZHOU, J. L.; LIU, Y. P.; ABRAHAMS, P. W. Trace metal behaviour in the Conwy estuary, North Wales. Chemosphere, v. 51, n. 5, p. 429-440, 2003.

ZWOLSMAN, J. J. G.; VAN ECK, G. T. M. Geochemistry of major elements and trace metals in suspended matter of the Scheldt estuary, southwest Netherlands. Mar. Chem., v. 66, n. 1-2, p. 91-111, 1999. 